\title{
Chronic self-administration of alcohol results in elevated $\Delta$ FosB: comparison of hybrid mice with distinct drinking patterns
}

Angela R Ozburn ${ }^{1,2^{*}}$, R D Mayfield ${ }^{1}$, Igor Ponomarev ${ }^{1}$, Theresa A Jones ${ }^{1}$, Yuri A Blednov ${ }^{1}$ and R A Harris ${ }^{1}$

\begin{abstract}
Background: The inability to reduce or regulate alcohol intake is a hallmark symptom for alcohol use disorders. Research on novel behavioral and genetic models of experience-induced changes in drinking will further our knowledge on alcohol use disorders. Distinct alcohol self-administration behaviors were previously observed when comparing two F1 hybrid strains of mice: (57BL/6J x NZB/B1NJ (BxN) show reduced alcohol preference after experience with high concentrations of alcohol and periods of abstinence while C57BL/6J x FVB/NJ (BxF) show sustained alcohol preference. These phenotypes are interesting because these hybrids demonstrate the occurrence of genetic additivity (BxN) and overdominance (BxF) in ethanol intake in an experience dependent manner. Specifically, BxF exhibit sustained alcohol preference and BxN exhibit reduced alcohol preference after experience with high ethanol concentrations; however, experience with low ethanol concentrations produce sustained alcohol preference for both hybrids. In the present study, we tested the hypothesis that these phenotypes are represented by differential production of the inducible transcription factor, $\triangle F o s B$, in reward, aversion, and stress related brain regions.
\end{abstract}

Results: Changes in neuronal plasticity (as measured by $\Delta$ FosB levels) were experience dependent, as well as brain region and genotype specific, further supporting that neuronal circuitry underlies motivational aspects of ethanol consumption. BxN mice exhibiting reduced alcohol preference had lower $\Delta$ FosB levels in the Edinger-Westphal nucleus than mice exhibiting sustained alcohol preference, and increased $\Delta$ FosB levels in central medial amygdala as compared with control mice. BxN mice showing sustained alcohol preference exhibited higher $\Delta$ FosB levels in the ventral tegmental area, Edinger-Westphal nucleus, and amygdala (central and lateral divisions). Moreover, in BxN mice $\Delta$ FosB levels in the Edinger-Westphal nucleus and ventral tegmental regions significantly positively correlated with ethanol preference and intake. Additionally, hierarchical clustering analysis revealed that many ethanol-naïve mice with overall low $\Delta$ FosB levels are in a cluster, whereas many mice displaying sustained alcohol preference with overall high $\Delta$ FosB levels are in a cluster together.

Conclusions: By comparing and contrasting two alcohol phenotypes, this study demonstrates that the reward- and stress-related circuits (including the Edinger-Westphal nucleus, ventral tegmental area, amygdala) undergo significant plasticity that manifests as reduced alcohol preference.

Keywords: Alcohol preference or consumption, Two-bottle choice, Hybrid mice, $\Delta$ FosB or FosB

\footnotetext{
* Correspondence: ozburna@gmail.com

${ }^{1}$ Waggoner Center for Alcoholism and Addiction Research, Institute for Neuroscience, University of Texas at Austin, Austin, TX 78712, USA

${ }^{2}$ Department of Psychiatry, University of Pittsburgh Medical Center, 450

Technology Dr. Ste. 223, Pittsburgh, PA 15219-3143, USA
}

\section{Biomed Central}

(c) 2012 Ozburn et al.; licensee BioMed Central Ltd. This is an Open Access article distributed under the terms of the Creative Commons Attribution License (http://creativecommons.org/licenses/by/2.0), which permits unrestricted use, distribution, and reproduction in any medium, provided the original work is properly cited. 


\section{Background}

There are known susceptibility factors, environmental and genetic, associated with alcohol abuse and alcoholism. The ability to drink copious amounts of alcohol with little consequence to the individual is a primary onset symptom in many alcoholics, indicating that a low level of response to alcohol is a major vulnerability factor in the development of alcoholism [1,2]. Defining neurobiological factors contributing to alcohol moderation will aid our understanding of alcohol use and abuse, and is an effective strategy for the development of improved treatments for individuals diagnosed with alcohol use disorders. Use of rodent models to imitate human disease has been a powerful tool in the advancement of understanding this disease and improving treatments. There are several rodent models in place to study aspects of alcohol abuse and alcoholism, however none model alcoholism completely. The extent to which a mouse will orally self-administer ethanol solutions under similar environmental conditions depends heavily on its genetic background [3]. Recently, we found that C57BL/ 6JxFVB/NJ (BxF) and FVB/NJxC57BL/6J (FVBxB6) F1 hybrid mice self-administer unusually high levels of alcohol during two-bottle preference tests (females consume $20-35 \mathrm{~g} / \mathrm{kg} /$ day and males $7-25 \mathrm{~g} / \mathrm{kg} /$ day, depending on concentration and paradigm) [4]. This new genetic model has a significant advantage when compared to existing inbred strains, including evidence of an overdominant phenotype and drinking to high blood alcohol levels [4]. Additionally, the high ethanol consumption exhibited by BxF mice is seen in two additional ethanol drinking paradigms (drinking in the dark and ethanol acceptance during scheduled fluid access) [4]. We then observed distinct alcohol self-administration behaviors when comparing two F1 hybrid strains of mice: C57BL/ 6J $x \mathrm{NZB} / \mathrm{B} 1 \mathrm{NJ}(\mathrm{BxN})$ show reduced alcohol preference after experience with high concentrations of alcohol and periods of abstinence and BxF show sustained alcohol preference [5]. Using a battery of behavioral tests, we have shown that $\mathrm{BxN}$ are more sensitive than $\mathrm{BxF}$ mice to the aversive and sedative, but not rewarding, effects of ethanol [6]. Basic research on novel behavioral and genetic models of high alcohol consumption and experience-induced changes in drinking will further our knowledge on alcohol abuse and alcoholism. The reduced alcohol preference phenotype is interesting because $\mathrm{BxN}$ mice initially show a high preference for ethanol solutions. Though the motivational aspect of reducing alcohol intake after experience with high ethanol concentrations and abstinence is unknown, $\mathrm{BxN}$ mice might be likened to moderate alcohol drinkers in that they still consume ethanol solutions but at a reduced level, presumably due to an aversive experience. The sustained alcohol preference model is also interesting, as $\mathrm{BxF}$ mice stably consume extremely high levels of ethanol regardless of previous experience. Sustained and reduced alcohol preference can be related to an alcohol deprivation effect, a phenomenon where animals exhibit significantly increased alcohol consumption after a period of forced abstinence [7]. The alcohol deprivation effect is a useful phenomenon for studying increased alcohol drinking behavior. Although the experimental schedule known to induce the alcohol deprivation effect is quite different than the schedule used here, comparing sustained and reduced alcohol preference to an alcohol deprivation effect relates the different behavioral phenotypes discussed here to an important phenomenon in rodent models of alcohol research. Reduced alcohol preference would be the opposite of an alcohol deprivation effect and sustained alcohol preference could be described as the absence of an alcohol deprivation effect. The use of diverse genetic animal models, such as $\mathrm{BxF}$ and $\mathrm{BxN}$, contributes greatly to the advancement of the field since alcohol use disorders are thought to arise from complex interactions between genetics and environment. Identification of differential immediate early gene expression for these hybrids offers insight into the brain circuitry important for the rewarding and aversive properties of ethanol.

Ethanol and other drug-engaged neurocircuits have been studied in specific rodent models using molecular markers of neuronal plasticity and/or activity [8-15]. Self-administered and experimenter-administered ethanol does not result in equivalent brain metabolic maps, suggesting specific circuitry underlies the reinforcing effects of ethanol $[8,9]$. One key component, yet to be extensively explored in alcohol research, is examination of sustained and reduced alcohol preference behaviors and identification of neuronal circuits engaged during these behaviors. The goal of this experiment was to identify brain regions engaged by sustained and reduced alcohol preference. Because chronic alcohol administration (along with other drugs of abuse) has been shown to cause brain regional differences in $\Delta$ FosB levels, we tested the hypothesis that these behavioral phenotypes are represented by differential production of the inducible transcription factor, $\triangle \mathrm{FosB}$, in brain regions known to be involved in reward, aversion, and stress [10].

Chronic stimuli that cause regional differences in $\Delta$ FosB levels include drugs of abuse (alcohol, cocaine, amphetamine, nicotine, morphine, and antipsychotics), chronic stress (restraint stress, unpredictable foot shock, electroconvulsive seizures), and compulsive wheel running [11]. As a potential mediator of long-term adaptations in the brain, identifying the dominant variant of FosB (FosB or $\Delta$ FosB) in response to chronic ethanol treatment is an important distinction. There are several studies that measured FosB and $\triangle$ FosB after chronic 
stimuli for which it has not been verified that $\Delta$ FosB was the dominant isoform (such as those described below). However, there is strong evidence that $\triangle$ FosB, not FosB, is the dominant isoform after chronic stimuli [10-12]. A study by Ryabinin and Wang (1998) found that in low alcohol preferring DBA/2J mice, four days of repeated ethanol injections resulted in robust increases in FosB expression in the following brain regions: anterior cortical amygdaloid nucleus, lateral septum ventrale, central amygdala, lateral amygdala, lateral hypothalamus, nucleus accumbens shell, bed nucleus of stria terminalis, and paraventricular nucleus of the thalamus [13]. Their results identify an ethanol-responsive neurocircuit. FosB expression has also been measured in the high alcohol preferring C57BL/6J mouse during acquisition and maintenance of ethanol self-administration under limited access conditions. There were no changes in FosB levels during acquisition of self-administration [14]. However, after two weeks of limited access ethanol self-administration, FosB levels were increased in the central medial nucleus of the amygdala and EdingerWestphal nucleus [15]. Overall, reports identify novel regions engaged in ethanol self-administration, as well as implicate a role for the mesocorticolimbic pathway and extended amygdala [16]. However, it is important to note that changes in $\triangle$ FosB levels depend on route of ethanol administration, dose, and length of time exposed to a treatment or schedule [13-15].

The mouse strains used in this study provide interesting models for comparison of sustained and reduced alcohol preference and the underlying mechanisms responsible for these distinct alcohol responses. This study demonstrates that mice exhibiting reduced alcohol preference also show significant plasticity in reward- and stress-related circuits (including the Edinger-Westphal nucleus, ventral tegmental area, amygdala, nucleus accumbens, and cingulate cortex).

\section{Results}

The effect of alcohol concentrations and abstinence periods on self-administration in BxF and BxN mice

To demonstrate that varying ethanol concentrations and/or abstinence periods changed subsequent ethanol consumption, we designed four schedules (groups) to measure ethanol consumption (Figure 1a,b). There were four experimental groups for each hybrid: High Concentrations, High Concentrations with Abstinence Periods, Low Concentrations, and Low Concentrations with Abstinence Periods. Complete data for ethanol preference (Figure 2) and consumption (Figure 3) data (for all groups and both genotypes) are presented for reference. To establish and illustrate the behavioral phenotypes of sustained and reduced alcohol preference, 9\% ethanol preference and consumption data is presented in
Figures 4 and 5 . These behavioral phenotypes are based on comparison of $9 \%$ ethanol preference and consumption from the first, second, third, and fourth presentation in the High Concentrations groups and corresponding experimental days for the Low Concentrations groups. A two way ANOVA (genotype $x$ time) of $9 \%$ ethanol preference and consumption was performed. For the High Concentrations group, ethanol preference (Figure 4a) and consumption (Figure 5a) were greater for $\mathrm{BxF}$ than $\mathrm{BxN}$, and $\mathrm{BxF}$ exhibited sustained alcohol preference and consumption while BxN exhibited reduced alcohol preference and consumption (ETHANOL PREFERENCE interaction $\mathrm{F}(3,54)=4.83, \mathrm{P}<0$. 01, genotype $\mathrm{F}(1,54)=$ 24.10, $\mathrm{P}<0.001$, time $\mathrm{F}(3,54)=9.92, \mathrm{P}<0.0001$; ETHANOL CONSUMPTION - interaction N/S, genotype $\mathrm{F}(1,54)=50.73, \mathrm{P}<0.0001$, time $\mathrm{F}(3,54)=11.68, \mathrm{P}<$ $0.0001)$. For the High Concentrations group with abstinence, ethanol preference (Figure $4 \mathrm{~b}$ ) and consumption (Figure $5 \mathrm{~b}$ ) were greater for $\mathrm{BxF}$ than $\mathrm{BxN}$, and $\mathrm{BxF}$ exhibited sustained alcohol preference and consumption while BxN exhibited reduced alcohol preference and consumption (ETHANOL PREFERENCE - interaction $\mathrm{F}(3,132)=15.89, \mathrm{P}<0.0001$, genotype $\mathrm{F}(1,132)=250.43$, $\mathrm{P}<0.0001$, time $\mathrm{F}(3,132)=27.48, \mathrm{P}<0.0001$; ETHANOL CONSUMPTION - interaction $\mathrm{F}(3,132)=11.35, \mathrm{P}<$ 0.0001 , genotype $\mathrm{F}(1,132)=510.88, \mathrm{P}<0.0001$, time $F(3,132)=22.42, P<0.0001)$. For the Low Concentrations group, ethanol preference (Figure 4c) and consumption (Figure 5c) were greater for $\mathrm{BxF}$ than $\mathrm{BxN}$, and both hybrids exhibited sustained alcohol preference and consumption (ETHANOL PREFERENCE - interaction N/S, genotype $\mathrm{F}(1,54)=12.2, \mathrm{P}<0.01$, time $\mathrm{N} / \mathrm{S}$; ETHANOL CONSUMPTION - interaction N/S, genotype $F(1,54)=$ $74.83, \mathrm{P}<0.0001$, time $\mathrm{N} / \mathrm{S})$. For the Low Concentrations group with abstinence, ethanol preference (Figure $4 \mathrm{~d}$ ) and consumption (Figure $5 \mathrm{~d}$ ) were greater for $\mathrm{BxF}$ than $\mathrm{BxN}$, and both hybrids exhibited moderate reductions in alcohol preference and consumption (ETHANOL PREFERENCE - interaction N/S, genotype $\mathrm{F}(1,132)=166.58, \mathrm{P}<0.0001$, time $\mathrm{N} / \mathrm{S} ; \mathrm{ETHANOL}$ CONSUMPTION - interaction $\mathrm{F}(3,132)=3.61, \mathrm{P}<0.05$, genotype $F(1,132)=480.64, P<0.0001$, time $F(3,132)=$ 7.87, $\mathrm{P}<0.0001)$. In summary, in High Concentrations groups (without abstinence), BxF exhibited sustained alcohol preference while BxN exhibited reduced alcohol preference and in the Low Concentrations groups (without abstinence), both BxF and B6xN exhibited sustained alcohol preference. Since the phenotypes of interest are best captured in groups without abstinence, they are the focus of the remainder of the study.

\section{$\Delta$ FosB Levels}

$\triangle$ FosB quantification and analysis was used to identify neurocircuitry chronically activated during sustained and 

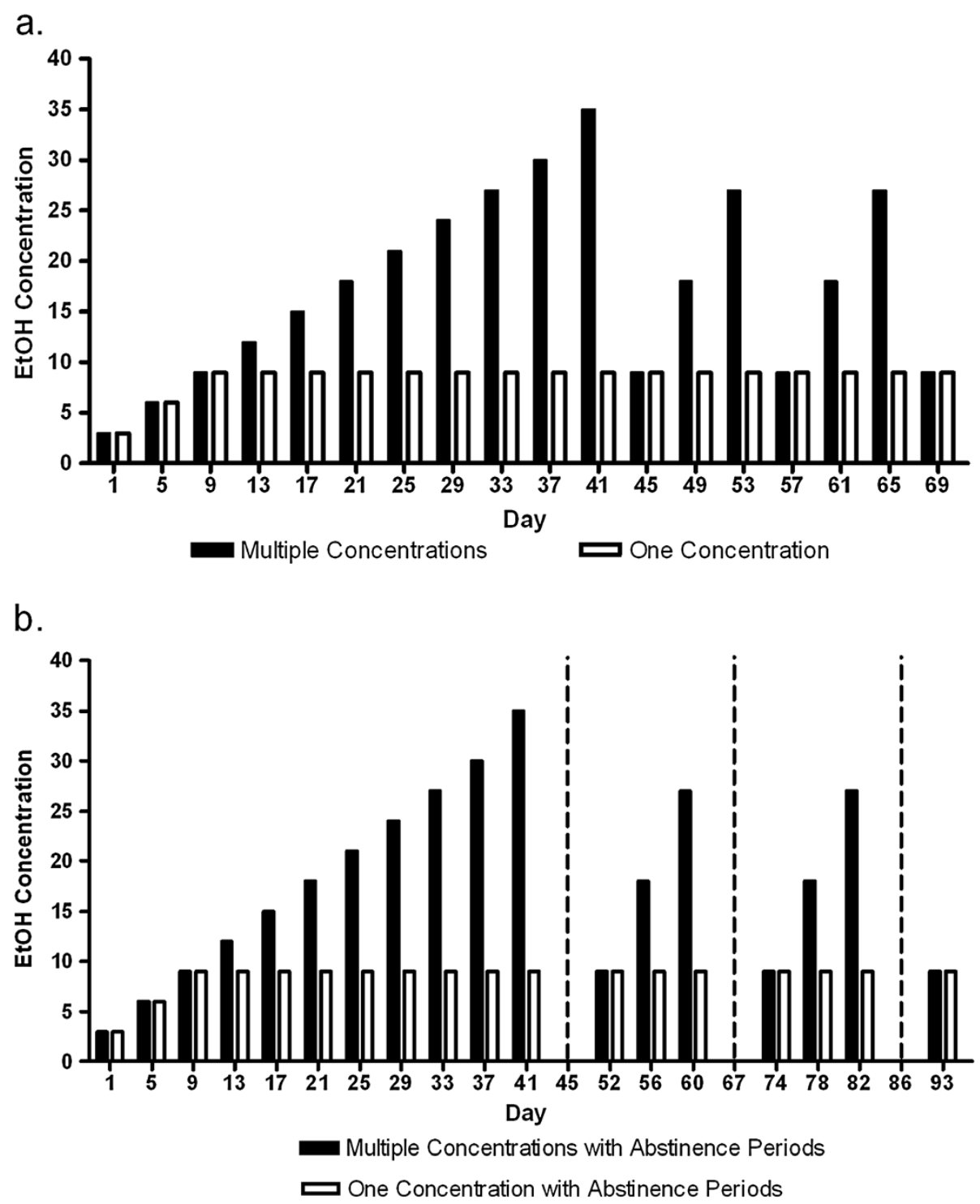

Figure 1 Experimental schedule for continuous access voluntary ethanol consumption. a. Experimental schedule for Low Concentrations and High Concentrations groups. b. Experimental schedule for Low Concentrations with Abstinence Periods and High Concentrations with Abstinence Periods. Dashed vertical lines indicate one week of abstinence. Ethanol (EtOH) concentration offered is percent ethanol $(\mathrm{v} / \mathrm{V}$, in tap water).

reduced alcohol preference. There were three experimental groups for each hybrid: High Concentrations, Low Concentrations, and Water (Control). $\triangle$ FosB data is presented as percent $\triangle \mathrm{FosB}$ positive neurons $[(\#$ of $\Delta$ FosB positive neurons) $/(\#$ of $\Delta$ FosB positive neurons + \# of Nissl positive neurons)] (Table 1). Previous work has shown that ethanol experience can induce neurodegeneration [17]. Therefore, we investigated neuronal numbers in this study and report no significant difference based on genotype or group for the brain regions quantified in this study. The following three analyses of $\triangle$ FosB data were performed: 1) three-way ANOVA (genotype $\mathrm{x}$ group $\mathrm{x}$ brain region), 2) two way ANOVA (brain region $\mathrm{x}$ group) for each genotype, and 3) correlation matrices were developed to map correlation networks.

Repeated measures three-way ANOVA (genotype $x$ group $\mathrm{x}$ brain region) revealed a genotype $\mathrm{x}$ brain region interaction $[\mathrm{F}(15,375)=2.01, \mathrm{P}<.05]$, a group $\mathrm{x}$ brain region interaction $[\mathrm{F}(15.375)=1.99, \mathrm{P}<0.01]$, and a main effect of brain region $[\mathrm{F}(15,375)=43.36, \mathrm{P}<.000]$. Repeated measures two-way ANOVA (brain region $\mathrm{x}$ group) for each genotype showed that there was a main effect of group and brain region for both $\mathrm{BxF}$ and $\mathrm{BxN}$ $[\mathrm{BxF}-\mathrm{F}(2,374)=11.79, \mathrm{P}<.0001$, main effect of group; $\mathrm{F}(15,374)=25.64, \mathrm{P}<.0001$, main effect of brain region; $\mathrm{BxN}-\mathrm{F}(2,360)=43.38, \mathrm{P}<.0001$, main effect of 


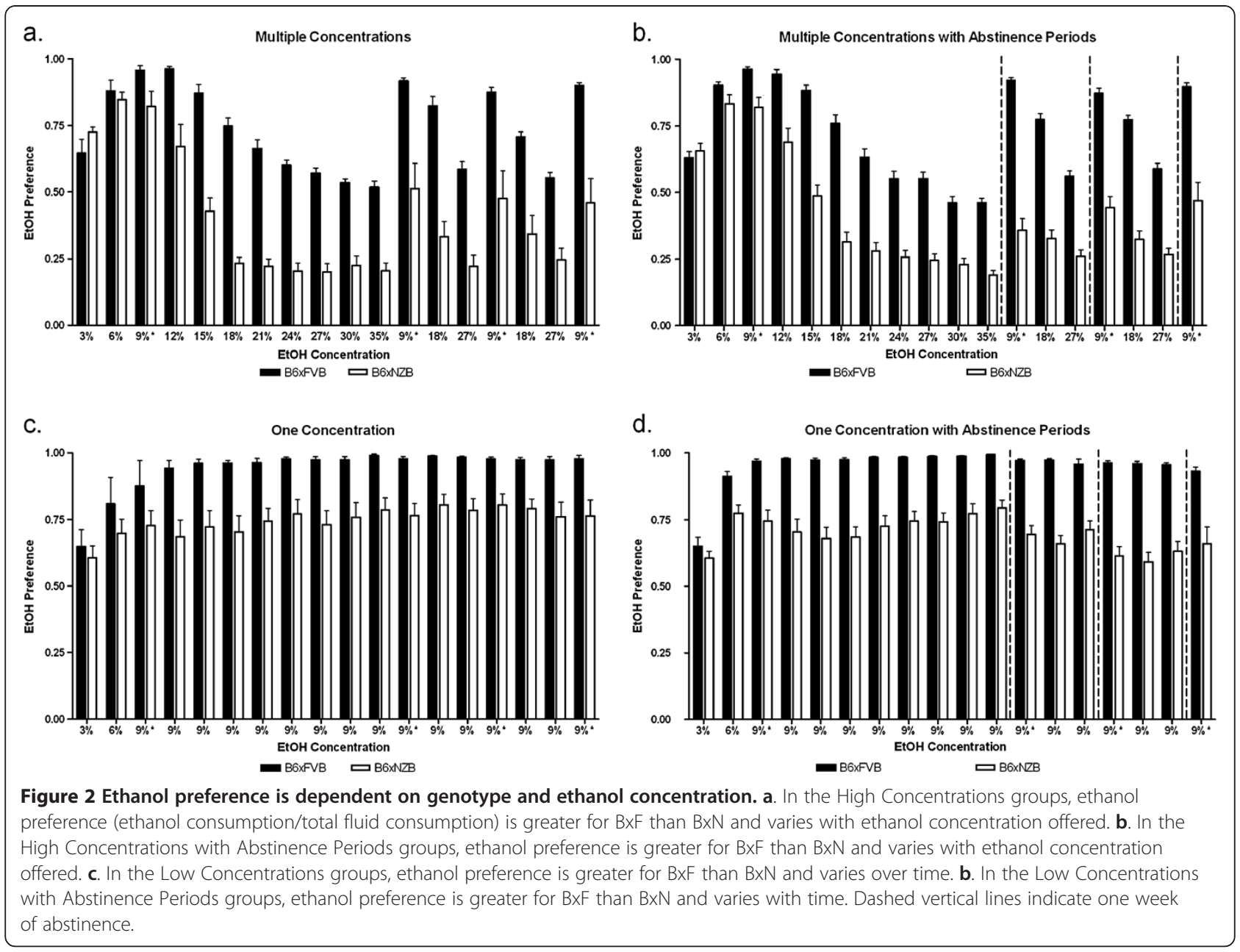

group; $\mathrm{F}(15,360)=23.73, \mathrm{P}<.0001$, main effect of genotype]. Post-hoc analysis revealed six significant group differences for $\mathrm{BxN}$ (Figure 6a-c). Percent $\triangle \mathrm{FosB}$ levels were higher in Low Concentrations group than in the Water group in $\mathrm{La}, \mathrm{CeC} / \mathrm{CeL}$, EW, and VTA. Percent $\triangle$ FosB was higher in the High Concentrations group than in the Water group in CeMPV. Percent $\triangle$ FosB was higher in the Low Concentrations group than in the High Concentrations group in EW. $\triangle$ FosB data for all other brain regions quantified are presented in Table 1. Pearson's $\mathrm{r}$ correlational analysis was used to determine if $\%$ of $\Delta \mathrm{FosB}$ positive neurons in a given brain region correlated with ethanol consumption or preference. Ethanol consumption and preference displayed a significant positive correlation with $\% \triangle \mathrm{FosB}$ in the EW and VTA of BxN mice (ETHANOL CONSUMPTION - EW $\mathrm{r}=0.85$; VTA $\mathrm{r}=0.85$; ETHANOL PREFERENCE - EW $\mathrm{r}=0.83$, VTA $\mathrm{r}=0.88 ; \mathrm{p}<0.05$ for all).

The complex relationship among $\Delta$ FosB expression, genotype, brain region, and ethanol consumption was further explored using principle component analysis and hierarchical clustering. Principal components analysis revealed that the majority of variability $(\sim 80 \%)$ in the data was represented by 5 components. Unsupervised hierarchical clustering (clustered by individuals and brain regions) was then performed and ordered using the first principal component (Figure 7). The individual clustering revealed strong, but not perfect, patterns of grouping based on ethanol consumption, regardless of genotype. Many of the ethanol-naïve mice clustered together and exhibited less overall $\Delta$ FosB than the mean and many of the mice that displayed sustained alcohol preference clustered together and exhibited more overall $\Delta$ FosB than the mean. These two clusters were the most divergent. The three clusters in between represented a greater than, less than, and mean mix of $\Delta$ FosB values and ethanol drinking phenotypes.

\section{Discussion}

Distinct alcohol self-administration behaviors were observed when comparing two F1 hybrid strains of mice: $\mathrm{BxN}$ show reduced alcohol preference after experience with high concentrations of alcohol and periods of abstinence while BxF show sustained alcohol preference. 


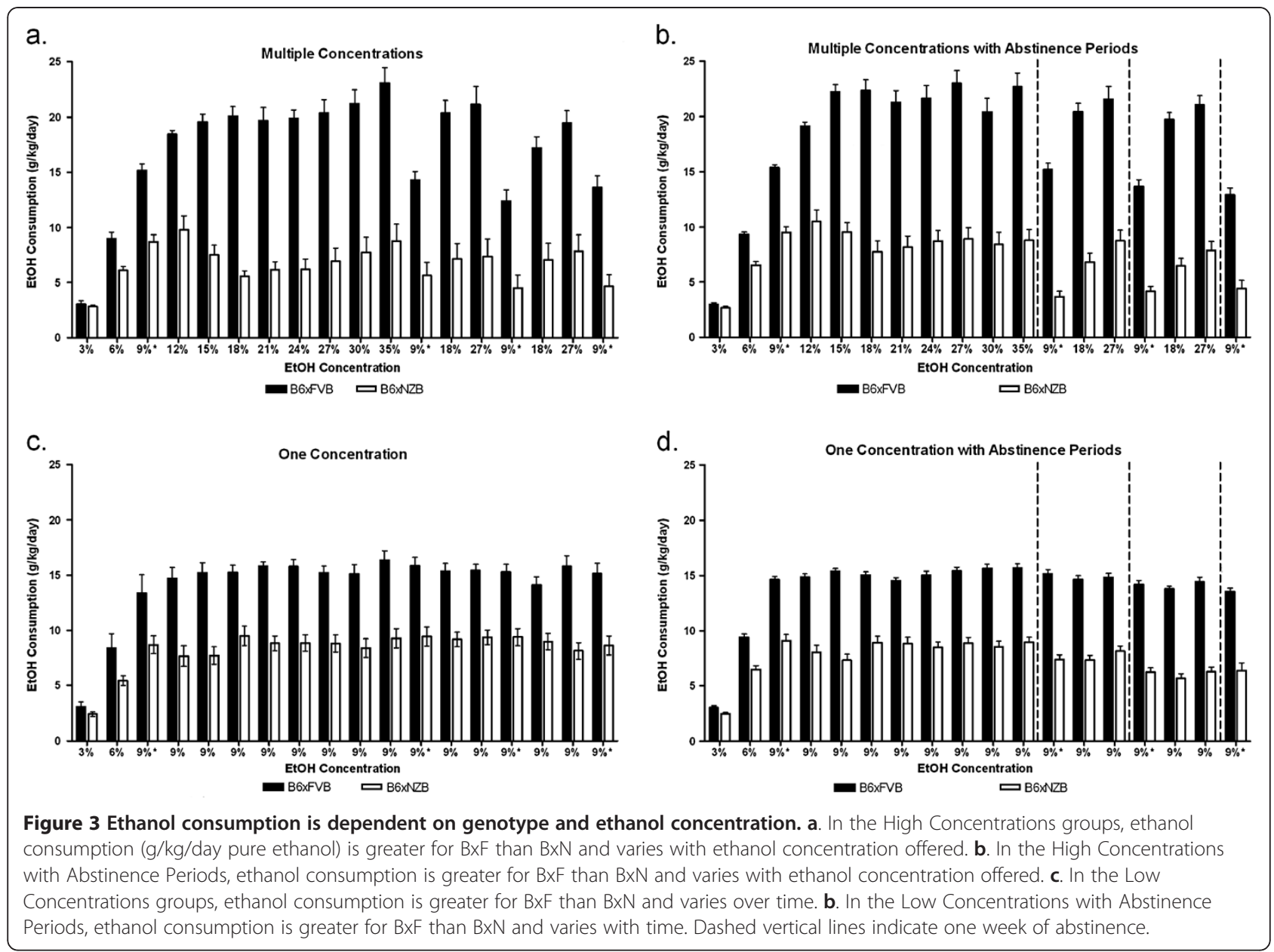

BxF models stable, high consumption (sustained alcohol preference) and $\mathrm{BxN}$ models moderate drinking (reduced alcohol preference). Neuronal plasticity (or activity, as measured by $\Delta$ FosB levels) was different depending on ethanol experience, further supporting an underlying role of specific neuronal circuitry in sustained and reduced alcohol preference.

For the high alcohol consuming strain, C57BL/6, ethanol preference and consumption are highly dependent on initial ethanol concentration, length of abstinence, and sub-strain $(\mathrm{C} 57 \mathrm{BL} / 6 \mathrm{Cr}$ or $\mathrm{C} 57 \mathrm{BL} / 6 \mathrm{~J})$ [7,18]. We found that the ethanol preference and consumption seen in BxF mice were consistently higher (and more stable than in $\mathrm{BxN}$ ) in the four different schedules tested. The moderately high ethanol preference and consumption in BxN were only sustained with one schedule of chronic drinking (Low Concentrations without abstinence), while reductions in preference and consumption were observed with all other chronic drinking schedules tested. BxN reduced alcohol preference offers a novel animal model in which experience (repeated presentation of ethanol after experience with multiple high ethanol concentrations and/or several short periods of abstinence) dramatically reduces their response to a previously highly preferred ethanol concentration.

Self-administered and experimenter-administered ethanol produce different brain metabolic maps, suggesting specific circuitry underlies the reinforcing effects of ethanol $[8,9]$. We tested the hypothesis that the sustained and reduced alcohol preference behavioral phenotypes are represented by differential production of the inducible transcription factor, $\triangle \mathrm{FosB}$, in brain regions known to be involved in reward, aversion, and stress. $\triangle \mathrm{FosB}$ is a transcription factor with a unique long-term stability and does not desensitize to stimuli as c-Fos does, rather it accumulates during chronic treatments. Increases in $\Delta \mathrm{FosB}$ are due to increased neuronal activity and are thought to reflect long-lasting neuronal plasticity. We found that the percent of $\Delta$ FosB positive neurons in brain regions depends on genotype (BxF and $\mathrm{BxN}$ ) and group (Water control, Low Concentrations, and High Concentrations).

For BxN, post-hoc analysis revealed that voluntary ethanol consumption resulted in increased $\Delta$ FosB in the 


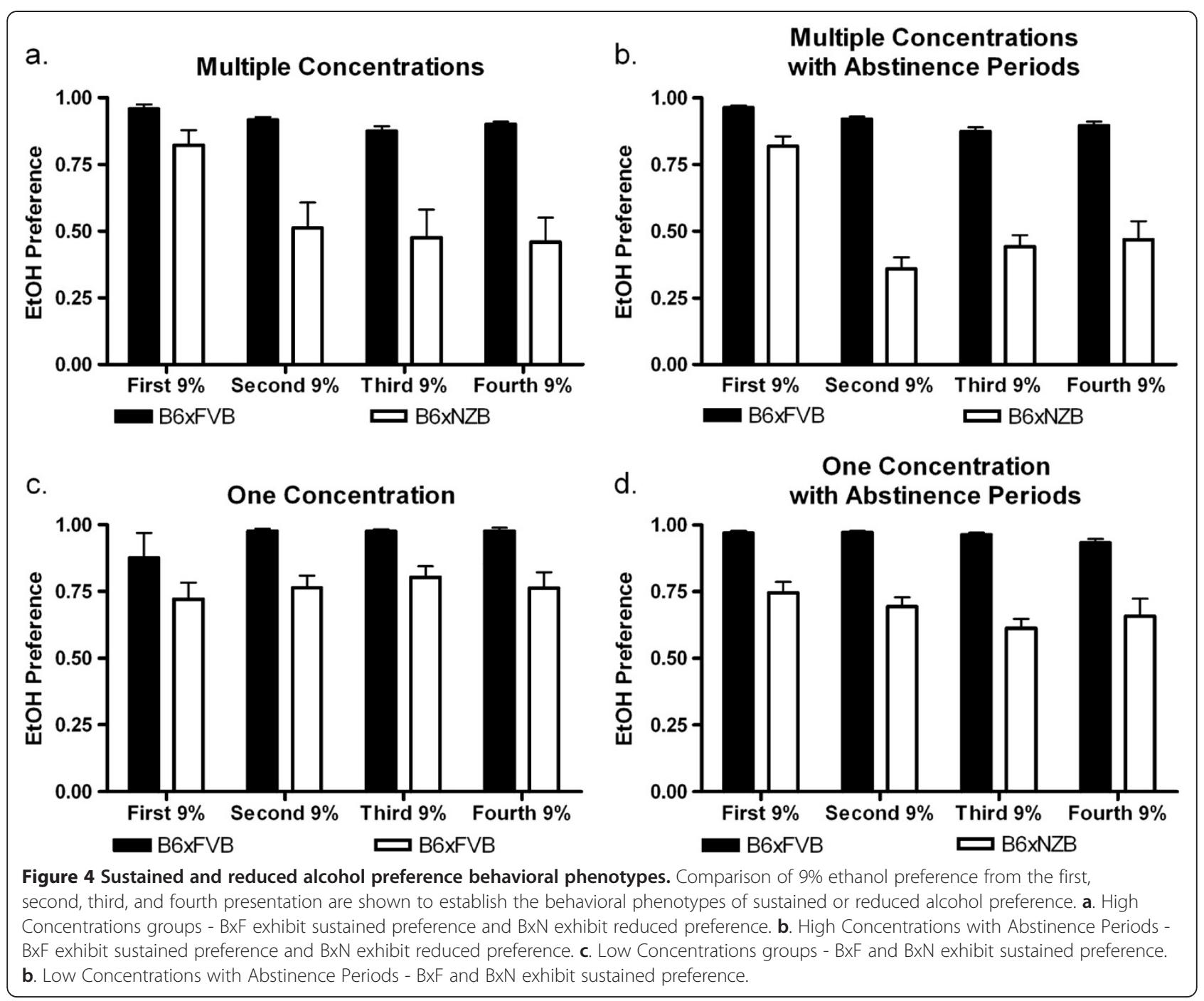

EW nucleus, VTA, and amygdala: indicating increased neuronal plasticity in brain regions known to be involved in ethanol, reward, and stress responses. BxN mice in the High Concentrations group (reduced alcohol preference) have reduced neuronal plasticity in the EW, suggesting that these neurons respond to alcohol intake with an experience-dependent plasticity. In the Low Concentrations group (exhibited sustained alcohol preference), neuronal plasticity in the EW is greater than in the High Concentrations and Water control groups. Although conducted using different ethanol drinking paradigms and genetic mouse models, our findings in the EW of BxN mice agree with previous ethanol consumption studies [14,15]. The non-preganglionic EW has recently been characterized as containing perioculomotor urocortin (Ucn)-containing neurons [19]. Ucn1 is a corticotropin releasing factor (CRF)-like peptide that binds CRF1 and CRF2 receptors. Previous studies using genetic, pharmacological, and lesion approaches have shown that Ucn1 is involved in regulating alcohol consumption [19-22]. There is a known genetic predisposition for high alcohol intake in rodents that is correlated with higher basal levels of Ucn1 in EW and LSi [23]. Thus, the lack of post-hoc significance that we observed in EW for high alcohol preferring and consuming BxF mice was unexpected. Perhaps this is due to the slightly elevated percent $\Delta$ FosB levels in the BxF water group as compared with $\mathrm{BxN}$ water group. Indeed, the percent $\Delta$ FosB levels for all mice exhibiting sustained alcohol preference (BxF High Concentrations group, BxF Low Concentrations group, and $\mathrm{BxN}$ Low Concentrations group) were quite similar.

For BxN, ethanol consumption in the Low Concentrations group increased neuronal plasticity in the VTA (greater than in the High Concentrations and Water control groups). Ethanol preference and consumption were also greater for the Low Concentrations group. The lack of post-hoc significance that we observed in 

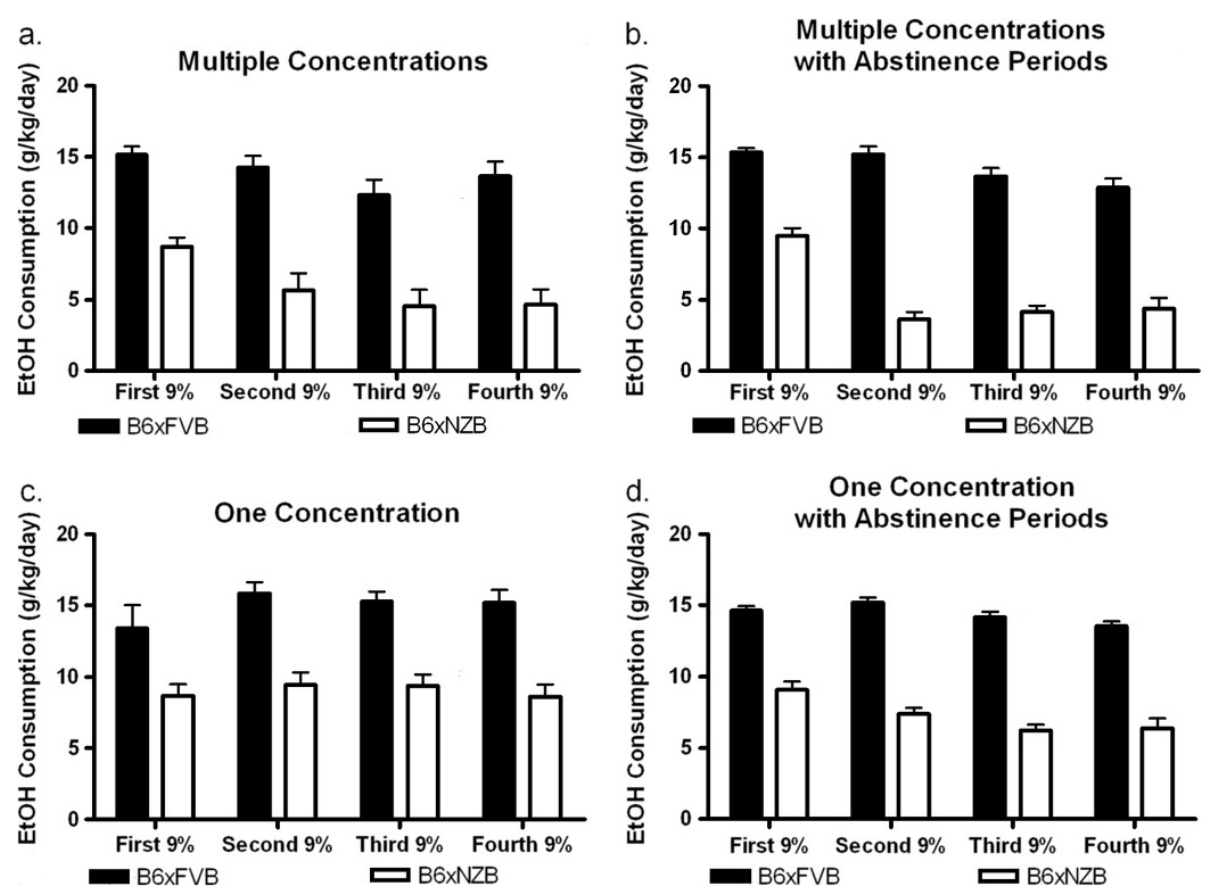

Figure 5 Sustained and reduced alcohol consumption behavioral phenotypes. Comparison of $9 \%$ ethanol consumption from the first, second, third, and fourth presentation are shown to establish the behavioral phenotypes of sustained or reduced alcohol consumption. a. High Concentrations groups - BxF exhibit sustained consumption and BxN exhibit reduced consumption. $\mathbf{b}$. High Concentrations with Abstinence Periods - BxF exhibit sustained consumption and BxN exhibit reduced consumption. $\mathbf{c}$. In the Low Concentrations groups, BxF and BxN exhibit sustained consumption. b. In the Low Concentrations with Abstinence Periods, BxF and BxN exhibit sustained consumption.

VTA for high alcohol preferring and consuming BxF mice was unexpected and may be due to slightly higher basal levels of $\triangle$ FosB in the water control group. Percent $\Delta$ FosB levels were slightly elevated in the $\mathrm{BxF}$ water group as compared with $\mathrm{BxN}$ water group, whereas the percent $\Delta$ FosB levels were quite similar for all mice exhibiting sustained alcohol preference (BxF High Concentrations group, BxF Low Concentrations group, and BxN Low Concentrations group). The VTA dopamine system plays a major role in mediating the reinforcing effects of ethanol and participates in many reciprocal connections important for ethanol and reward-related behaviors [24-26]. Additionally, the VTA projects to the amygdala and EW nucleus. Rats have been shown to self-administer ethanol directly into the VTA [27]. Also, ethanol exposure increases the firing rate of dopaminergic neurons in VTA $[28,29]$. Increased firing rate could be linked to the $\triangle$ FosB induction in the VTA that we observed following chronic voluntary ethanol administration in $\mathrm{BxN}$.

Alcohol dependence induces long-term neuroadaptations, resulting in negative emotional states; an important

Table 1 Percent $\Delta$ FosB Positive Neurons

\begin{tabular}{|c|c|c|c|c|c|c|}
\hline Genotype Group & BxF Control & BxF High Conc. & BxF Low Conc. & BxN Control & BxN High Conc. & BxN Low Conc. \\
\hline IL & $56 \pm 6$ & $67 \pm 4$ & $66 \pm 5$ & $44 \pm 4$ & $59 \pm 4$ & $62 \pm 5$ \\
\hline Cg1 & $63 \pm 7$ & $73 \pm 3$ & $65 \pm 6$ & $50 \pm 5$ & $70 \pm 5$ & $58 \pm 5$ \\
\hline Cg2 & $63 \pm 7$ & $70 \pm 5$ & $62 \pm 7$ & $49 \pm 5$ & $70 \pm 5$ & $60 \pm 6$ \\
\hline NAcc core & $61 \pm 4$ & $69 \pm 3$ & $70 \pm 5$ & $55 \pm 2$ & $69 \pm 4$ & $64 \pm 3$ \\
\hline NAcc shell & $49 \pm 3$ & $62 \pm 2$ & $61 \pm 5$ & $45 \pm 3$ & $61 \pm 3$ & $57 \pm 3$ \\
\hline $\mathrm{LSi}$ & $16 \pm 4$ & $22 \pm 3$ & $25 \pm 4$ & $19 \pm 4$ & $22 \pm 2$ & $29 \pm 4$ \\
\hline PAG & $24 \pm 6$ & $26 \pm 5$ & $30 \pm 6$ & $21 \pm 5$ & $26 \pm 4$ & $38 \pm 7$ \\
\hline DR & $20 \pm 7$ & $26 \pm 4$ & $28 \pm 5$ & $20 \pm 6$ & $23 \pm 4$ & $30 \pm 7$ \\
\hline PBN & $28 \pm 6$ & $31 \pm 3$ & $36 \pm 6$ & $20 \pm 6$ & $28 \pm 5$ & $35 \pm 8$ \\
\hline NTS & $27 \pm 8$ & $21 \pm 2$ & $20 \pm 4$ & $18 \pm 5$ & $23 \pm 4$ & $21 \pm 5$ \\
\hline
\end{tabular}

Percent $\Delta$ FosB positive neurons $=$ (\# of $\Delta$ FosB positive neurons)/(\# of $\Delta$ FosB positive neurons + \# of Nissl positive neurons). 


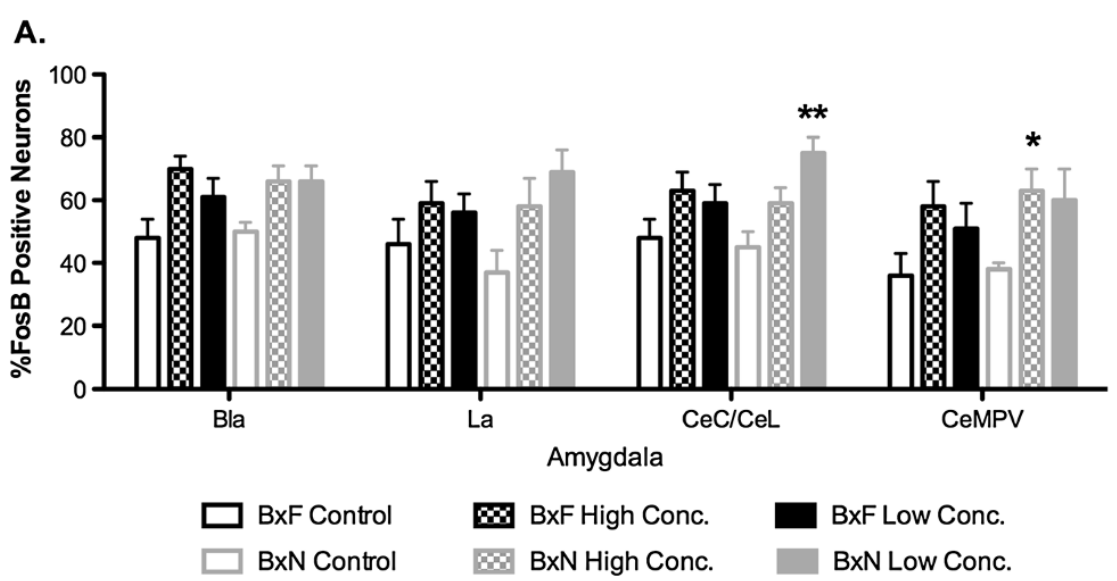

B.

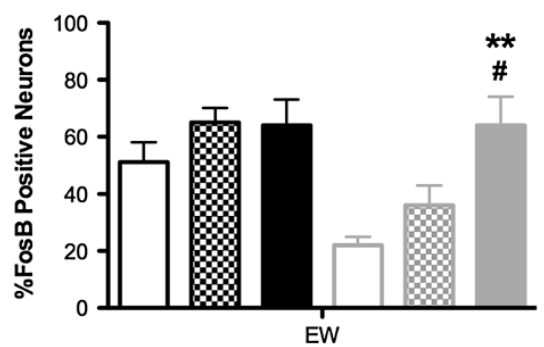

D.
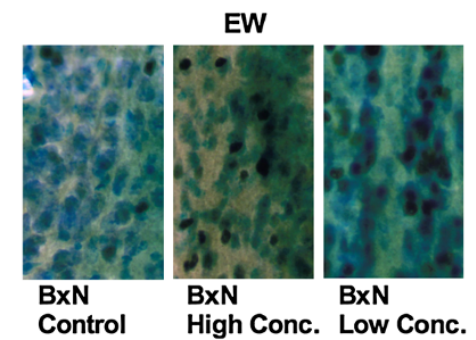

C.

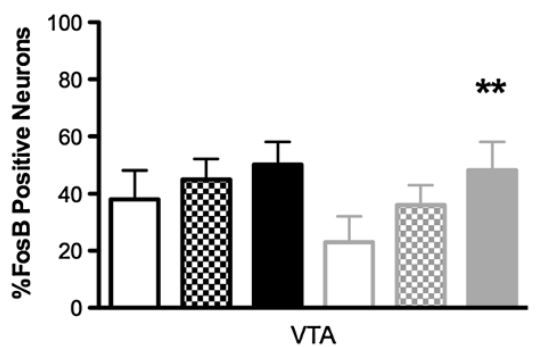

E.

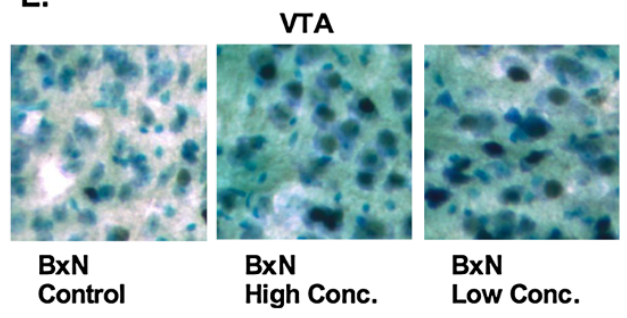

Figure 6 Sustained and reduced alcohol preference induce $\triangle$ FosB in the amygdala, EW, and VTA. Percent $\triangle$ FosB positive neurons in regions of the amygdala (a.), EW (b.), and VTA (c.). $\mathbf{d}$. and $\mathbf{e}$. Representative images of $\Delta$ FosB/Nissl staining for regions where $\% \Delta$ FosB positive cells significantly correlated with alcohol preference and consumption. Percent $\Delta$ FosB positive neurons $=$ (\# of $\Delta$ FosB positive neurons)/ (\# of $\Delta$ FosB positive neurons + \# of Nissl positive neurons). Bonferroni post-hoc results (corrected for multiple comparisons): ${ }^{*}=\mathrm{P}<.05$, ** $=\mathrm{P}<.01$ significant difference from Control group; \# $=\mathrm{P}<.05$, significant difference from High Conc. Group.

mechanism in negative reinforcement is corticotropinreleasing factor (CRF) signaling within the amygdala [30]. Pharmacological manipulations of neurons in the CeA have targeted GABA, CRF, opioid, serotonin, dynorphin, and norepinephrine receptors [25,31-34]. GABA antagonists, as well as CRF antagonists, decrease ethanol consumption $[32,33,35]$. Lesions of the CeA decrease continuous access voluntary ethanol consumption [36]. Our findings further support a role for $\mathrm{CeA}$ in the regulation alcohol drinking behavior. GABAergic neurons in the central amygdala form a heterogeneous population whose connections appear related to their peptide content. These GABAergic neurons integrate output activity of the CeA. As reviewed in Wee and Koob (2010), several studies have identified a role for dynorphin and kappa opioid receptors in the maintenance and escalation of ethanol intake [37]. More recently, Walker et al has demonstrated that the $\mathrm{k}$-opioid receptor antagonist, nor-binaltorphimine, within the extended amygdala selectively reduces ethanol self-administration in dependent animals [38]. Kappa opioid receptor signaling remains a key interest of research at the intersection of stress, reward, and aversion. It has also been demonstrated that stress-induced ethanol self-administration is mediated by kappa opioid receptor signaling [39]. The central CeA can be subdivided into the latero-capsular $(\mathrm{CeL} / \mathrm{CeC})$ and medial posterior ventral. GABAergic neurons of the $\mathrm{CeL} / \mathrm{CeC}$ receive dopaminergic innervations 


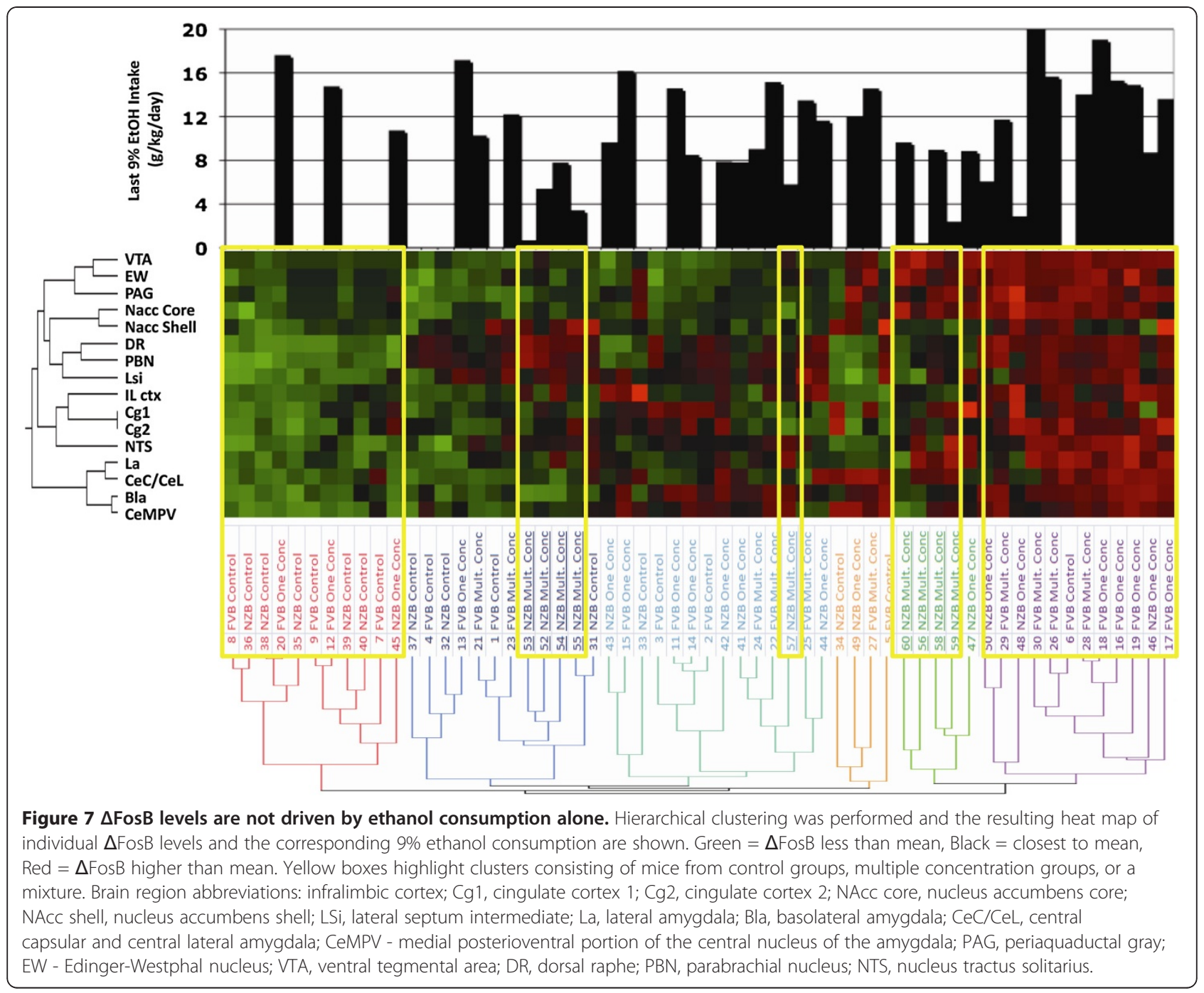

from the VTA; as previously noted, these neurons are activated after acute ethanol administration and show increased $\triangle$ FosB mice showing sustained alcohol preference. Also, see McBride (2002) for an excellent review on CeA and the effects of alcohol [40]. In our study, $\mathrm{BxN}$ mice with sustained alcohol preference (Low Concentrations group) exhibited increased neuronal plasticity in the $\mathrm{CeC} / \mathrm{CeL}$ and $\mathrm{La}$ and $\mathrm{BxN}$ mice with reduced alcohol preference (High Concentrations group) exhibit increased neuronal plasticity in the CeMPV. These results suggest that specific ethanol experience involves plasticity in GABAergic neurons in the amygdala. With this data, along with corresponding changes in neuronal plasticity in the VTA and EW, we propose this circuit undergoes significant plasticity under sustained alcohol preference conditions.

Previous research has shown that C57BL/6J mice can achieve high blood alcohol levels by two bottle choice drinking, however these blood alcohol levels are not sustained and often the drinking does not meet criteria for pharmacological motivation set forth by Dole and Gentry (1984) [41,42]. BxN mice exhibiting reduced alcohol preference consumed less than would be expected from a typical C57BL/6J mouse [1]. Therefore, although we did not take blood alcohol samples, it is not likely that $\mathrm{BxN}$ mice showing reduced alcohol preference achieved sustained pharmacologically relevant blood alcohol levels, suggesting high blood alcohol concentrations of are not necessary to induce plasticity on these brain regions. It is important to note that a highly significant effect of group also exists in BxF, even though post-hoc results (corrected for multiple comparisons) for BxF brain regions did not indicate significant changes in percent $\Delta$ FosB positive neurons for any region following chronic ethanol consumption with these different schedules.

In order to visualize potential relationships among variables hierarchical clustering was performed. The heatmap of the resulting analysis shows a general trend 
between $\triangle$ FosB levels and ethanol consumption regardless of genotype. Higher $\Delta$ FosB levels were associated with high drinking and lower $\Delta$ FosB levels were associated with control animals; however, the strength of the relationship was not sufficient to accurately predict drinking phenotypes based solely on $\Delta$ FosB levels.

\section{Conclusions}

Distinct alcohol self-administration behaviors were observed with two F1 hybrid strains of mice: $\mathrm{BxN}$ show reduced alcohol preference after experience with high concentrations of alcohol while BxF show sustained alcohol preference. BxF models stable, high consumption (sustained alcohol preference) and BxN models moderate drinking (reduced alcohol preference). Changes in neuronal plasticity (as measured by $\Delta$ FosB levels) were experience-dependent, as well as brain region- and genotype-specific, further defining the neuronal circuitry underlies motivational aspects of ethanol consumption. These results show that the change of one parental line in hybrid mice results in changes in patterns of alcohol consumption and marked changes in patterns of $\Delta$ FosB expression, suggesting that distinct brain networks are engaged in these different hybrid mice.

\section{Methods}

\section{Ethics}

This study was carried out in strict accordance with the recommendations in the Guide for the Care and Use of Laboratory Animals of the National Institutes of Health. The protocol was approved by the Institutional Animal Care and Use Committee of the University of Texas at Austin (AUP 2010-00028). All surgery was performed under sodium pentobarbital anesthesia, and all efforts were made to minimize suffering.

\section{Animals}

Studies were conducted using intercross female F1 hybrid mice derived from $\mathrm{C} 57 \mathrm{BL} / 6 \mathrm{~J}$ and either $\mathrm{FVB} / \mathrm{NJ}$ or $\mathrm{NZB} / \mathrm{B} 1 \mathrm{NJ}$ mice $(\mathrm{BxF} F 1$ and $\mathrm{BxN} F 1$, maternal strain $\mathrm{x}$ paternal strain). $\mathrm{C} 57 \mathrm{BL} / 6 \mathrm{~J}, \mathrm{FVB} / \mathrm{NJ}$, and $\mathrm{NZB} / \mathrm{B} 1 \mathrm{NJ}$ breeders were purchased from The Jackson Laboratory (Bar Harbor, ME) and mated at 7-8 weeks. Offspring were weaned into isosexual groups of each of the genotypes (BxF F1, BxN F1). We tested only female mice to facilitate comparison with previously collected data $[1,5,6]$. Mice were housed in standard cages with food and water provided ad libitum. The colony room and testing room were on a $12 \mathrm{~h}$ light: $12 \mathrm{~h}$ dark cycle (lights on at 07:00).

\section{Two bottle choice ethanol preference test}

The two bottle choice method was used to determine voluntary ethanol self-administration patterns in female
$\mathrm{BxF}$ and $\mathrm{BxN}$ mice [1,6]. F1 hybrid female mice (age 63 days) were individually housed in standard cages while habituating for one week to bottles with sipper tubes containing water before introduction of an ethanol solution. After habituation, mice had access to two identical bottles: one containing water and the other containing an ethanol solution. Tube positions were changed daily to control for position preferences. To account for potential spillage and evaporation, the average weight depleted from tubes in control cages without mice was subtracted from individual drinking values each day. Mice were weighed every 4 days throughout the experiment. All fluid consumption was measured daily throughout the experiment. The quantity of ethanol consumed and ethanol preference were calculated for each mouse, and these values were averaged for every concentration of ethanol. The effect of alcohol concentrations and abstinence periods on self-administration in BxF and BxN mice was demonstrated by designating an experimental group with access to High Concentrations (escalating access to 3-35\% ethanol solutions, followed by 3 repeated cycles of 9, 18, and 27\% ethanol, ending with a final presentation of $9 \%$ ethanol) and another group with Low Concentrations (escalating access to $3-9 \%$ ethanol, with the remainder of the experiment carried out with access to $9 \%$ ethanol). Each of these groups had a subgroup that did or did not experience three one-week periods of abstinence. Control mice experienced similar conditions at the same time as experimental mice, but were only offered one bottle of water.

In total, there were five groups for each hybrid: Water $(n=14-16)$, High Concentrations $(n=10)$, High Concentrations with Abstinence Periods $(n=20)$, Low Concentrations $(n=10)$, and Low Concentrations with Abstinence Periods $(n=20)$. Refer to Figure 1 for detailed two bottle choice group schedules.

\section{$\Delta$ FosB Immunohistochemistry and quantification}

$\Delta$ FosB immunohistochemistry (IHC) was measured in 16 brain regions from mice that experienced 72 days of continuous access to either water (Control) or water \& alcohol [High Concentrations and Low Concentrations]. The effect of High Concentrations on ethanol preference and consumption was much greater than the effect of abstinence; therefore, groups which experienced periods of abstinence were not included in $\triangle$ FosB IHC measurements. Further, the experiment was carried out beyond the first appearance of sustained or reduced alcohol preference to show the behavioral phenotypes are stable with repeated cycles of ethanol concentration changes to examine the effects of chronic ethanol consumption. Four to eight hours after removing alcohol on the 73rd day of the experiment, mice were deeply anesthetized (175 mg/kg sodium pentobarbital) and perfused 
intracardially with $20 \mathrm{ml}$ of $0.01 \mathrm{M}$ phosphate buffered saline (PBS), followed by $100 \mathrm{ml}$ of $4 \%$ paraformaldehyde in PBS. Brains were removed, post-fixed in $4 \%$ paraformaldehyde at $4^{\circ} \mathrm{C}$, embedded in $3 \%$ agarose, sectioned (50 um, coronal) on a vibratome, placed in cryoprotectant (30\% sucrose, $30 \%$ ethylene glycol, and $0.1 \%$ polyvinyl pyrrolidone in $\mathrm{PBS}$ ) overnight at $4^{\circ} \mathrm{C}$, and stored at $-20^{\circ} \mathrm{C}$ until processed for IHC. Thawed sections were washed with PBS, treated with $0.3 \% \mathrm{H} 2 \mathrm{O} 2$, and incubated for one hour in 3\% normal goat serum to minimize non-specific labeling. Tissue sections were then incubated overnight at $4^{\circ} \mathrm{C}$ in $3 \%$ normal goat serum and anti-FosB (SC-48, 1:5000 dilution, Santa Cruz Biotechnology, Santa Cruz, CA). Sections were washed, incubated in biotinylated goat anti-rabbit Ig (1:200 dilution, Vector Laboratories, Burlingame, CA) for one hour, washed, and incubated in avidin-biotin complex (1:200 dilution, Elite kit-Vector Laboratories). Peroxidase activity was visualized by reaction with $0.05 \%$ diaminobenzidine (containing $0.015 \% \quad \mathrm{H}_{2} \mathrm{O}_{2}$ ). Tissue sections were Nissl counterstained (using methylene blue/azure II). Slides were coded for blind counting. $\Delta$ FosB-IR neurons were counted at $50 \mathrm{X}$ (oil) magnification using the optical fractionator method and StereoInvestigator computer software. Sampling parameter information: the counting frame (50um x 50um x 10um) was the same for all regions quantified; however, the grid size was determined for each brain region to ensure that total bilateral cell counts would equal 100-300 in order to achieve a coefficient of variation less than 0.1. Data was calculated as percent of $\Delta$ FosB positive nuclei (number of $\Delta$ FosB positive nuclei/number of neurons) for each region.

The FosB antibody used in this study (SC-48, Santa Cruz Biotechnology, Santa Cruz, CA) was raised against an internal region of FosB and recognizes both FosB and $\Delta$ FosB. Although this antibody recognizes both FosB and $\triangle F o s B$, the immunopositive neurons quantified in this study will be referred to as $\Delta$ FosB positive neurons since it has been shown that drugs of abuse, including alcohol, specifically induce $\triangle \mathrm{FosB}$, not FosB, in neurons. Perrotti et al. (2008) measured $\Delta$ FosB induction (in response to chronic administration of drugs of abuse, including alcohol) using two antibodies: one which recognizes FosB and $\triangle$ FosB (SC-48) and one selective for $\triangle F$ FosB (not commercially available) and found that for all drugs studied, the immunoreactivity observed using the FosB antibody (SC-48) is due to $\Delta$ FosB, since they did not detect any immunoreactive neurons using an antibody selective for full-length FosB [10]. Additionally, $\triangle \mathrm{FosB}$ is known to be induced in a brain region- and cell-type-specific manner, by various chronic treatments and excellent reviews on this topic are available $[11,43,44]$.

\section{Abbreviations and locations of neuroanatomical structures}

Il - infralimbic cortex $(+1.70 \mathrm{~mm})$; Cg1 - cingulate cortex $1(+1.1 \mathrm{~mm}) ; \mathrm{Cg} 2$ - cingulate cortex $1(+1.10 \mathrm{~mm})$; NAcc core - nucleus accumbens core $(+1.10 \mathrm{~mm})$; NAcc shell - nucleus accumbens shell $(+1.10 \mathrm{~mm})$; LSi lateral septum intermediate $(+1.10 \mathrm{~mm})$; $\mathrm{La}$ - lateral amygdala $(-1.22 \mathrm{~mm})$; Bla - basolateral amygdala $(-1.22$ $\mathrm{mm}) ; \mathrm{CeC} / \mathrm{CeL}-$ central capsular and central lateral amygdala $(-1.22 \mathrm{~mm})$; CeMPV - medial posterioventral portion of the central nucleus of the amygdala $(-1.22 \mathrm{~mm})$; PAG - periaquaductal gray $(-3.64 \mathrm{~mm})$; EW - Edinger-Westphal nucleus $(-3.64 \mathrm{~mm})$; VTA ventral tegmental area $(-3.64 \mathrm{~mm})$; DR - dorsal raphe $(-4.60 \mathrm{~mm})$; PBN - parabrachial nucleus $(-5.2 \mathrm{~mm})$; NTS - nucleus tractus solitarius $(-6.96 \mathrm{~mm})$. The Mouse Brain in Stereotaxic Coordinates [45] was used to subjectively match one to three sections for quantification of each brain region.

\section{Statistical procedures}

Data are reported as the mean \pm S.E.M., except where otherwise noted. Data were normally distributed. Statistics were performed using Statistica version 6 (StatSoft, Tulsa, OK, USA) and GraphPad Prism version 4.00 (GraphPad Software, San Diego, CA, USA). Repeated measures two-way ANOVAs were carried out for ethanol consumption and preference data to evaluate differences between groups. Two and three-way ANOVAs were carried out for $\triangle$ FosB data to evaluate interactions and main effects for group (High Concentrations, Low Concentrations, and Water), brain region, and genotype. Bonferroni's correction for multiple comparisons and Bonferroni's post-hoc were carried out when appropriate. Specifically, we hypothesized that the stress and reward circuitry would have increased FosB in mice showing reduced alcohol preference. For each hybrid cross, Pearson's $r$ was used to identify the presence of significant correlations between $\Delta$ FosB levels and ethanol preference and consumption in ethanol-experienced mice.

Hierarchical clustering was carried out in order to visualize how the data co-vary and assess how the data group together. Imputed median values replaced missing percent $\Delta$ FosB data, which did not exceed $15 \%$ of data. Although there is a greater degree of uncertainty than if the imputed values had actually been observed, hierarchical clustering analysis requires complete membership or complete deletion for case-wise comparisons. Hierarchical clustering was performed using Ward's method and the resulting clusters were ordered by the first principle component of a principal component analysis $\left(\mathrm{JMP}^{\circledR}\right.$, Version 8, SAS Institute Inc., Cary, NC). For water and ethanol-experienced groups, the $\Delta$ FosB data for each brain region was $\mathrm{z}$-score transformed and principal 
components analysis was carried out to determine the number of clusters. The data was then clustered by brain regions and individuals using supervised hierarchical clustering analysis.

\section{Competing interests}

The authors declare that they have no competing interests.

\section{Authors' contributions}

$A R O, Y A B, R A H, T A J$ contributed to the design of the study. ARO acquired the data. ARO, IP, RDM analyzed the data. ARO, RDM, IP, TAJ, YAB, and RAH were involved in drafting and revising the manuscript. All authors read and approved the final manuscript.

\section{Acknowledgements}

We would like to thank Drs. Jody Mayfield and Colleen McClung for helpful discussions and Marni Martinez, Jennifer Stokes, Michelle Foshat, Jose Cienfuegos, Jamie Seymour, and Darshan Pandya for technical assistance. This research was supported by the Integrative Neuroscience Initiative on Alcoholism Consortium Grant AA13520, and National Institute on Alcohol Abuse and Alcoholism Grants AA06399-S and AA16424.

Received: 3 May 2012 Accepted: 12 October 2012

Published: 29 October 2012

\section{References}

1. Garcia-Andrade C, Wall TL, Ehlers CL: The firewater myth and response to alcohol in Mission Indians. Am J Psychiatry 1997, 154:983-988.

2. Schuckit MA, Smith TL, Kalmijn J: Findings across subgroups regarding the level of response to alcohol as a risk factor for alcohol use disorders: a college population of women and Latinos. Alcohol Clin Exp Res 2004, 10:1499-1508

3. Belknap JK, Crabbe JC, Young ER: Voluntary consumption of ethanol in 15 inbred mouse strains. Psychopharmacology 1993, 112:503-510.

4. Blednov YA, Metten P, Finn DA, Rhodes JS, Bergeson SE, Harris RA, Crabbe JC: Hybrid C57BL/6J x FVB/NJ mice drink more alcohol than do C57BL/6J mice. Alcohol Clin Exp Res 2005, 29:1949-1958.

5. Blednov YA, Ozburn AR, Walker D, Ahmed S, Belknap JK, et al: Hybrid mice as genetic models of high alcohol consumption. Behav Genet 2010, 40:93-110.

6. Ozburn AR, Harris RA, Blednov YA: Behavioral differences between C57BL/ 6JxFVB/NJ and C57BL/6JxNZB/B1NJ F1 hybrid mice: relation to control of ethanol intake. Behav Genet 2010, 40:551-563.

7. Melendez RI, Middaugh LD, Kalivas PW: Development of an alcoho deprivation and escalation effect in C57BL/6J. Alcohol Clin Exp Res 2006, 30:2017-2025

8. Porrino $L$, Whitlow $C T$, Samson HH: Effects of the self-administration of ethanol and ethanol/sucrose on rates of local cerebral glucose utilization in rats. Brain Res 1998, 791(1-2):18-26.

9. Williams-Hemby L, Porrino LJ: Low and moderate doses of ethanol produce distinct patterns of cerebral metabolic changes in rats. Alcohol Clin Exp Res 1994, 18(4):982-988.

10. Perrotti LI, Weaver RR, Robison B, Renthal W, Maze I, Yazdani S, Elmore RG, Knapp DJ, Selley DE, Martin BR, Sim-Selley L, Bachtell RK, Self DW, Nestler EJ: Distinct patterns of DeltaFosB induction in brain by drugs of abuse. Synapse 2008, 62(5):358-369.

11. McClung CA, Ulery PG, Perrotti LI, Zachariou V, Berton O, Nestler EJ: DeltaFosB: a molecular switch for long-term adaptation in the brain. Brain Res Mol Brain Res 2004, 132:146-154.

12. Perrotti $L I$, Bolaños $C A$, Choi KH, Russo SJ, Edwards S, Ulery PG, Wallace DL, Self DW, Nestler EJ, Barrot M: DeltaFosB accumulates in a GABAergic cell population in the posterior tail of the ventral tegmental area after psychostimulant treatment. Eur J Neurosci 2005, 21:2817-2824.

13. Ryabinin $A E$, Wang $Y M$ : Repeated alcohol administration differentially affects c-Fos and FosB protein immunoreactivity in DBA/2J mice. Alcohol Clin Exp Res 1998, 22:1646-1654.

14. Ryabinin AE, Bachtell RK, Freeman P, Risinger FO: ITF expression in mouse brain during acquisition of alcohol self-administration. Brain Res 2001, 890:192-195.
15. Bachtell RK, Wang YM, Freeman P, Risinger FO, Ryabinin AE: Alcohol drinking produces brain region-selective changes in expression of inducible transcription factors. Brain Res 1999, 847(2):157-165.

16. Kalivas PW: How do we determine which drug-induced neuroplastic changes are important? Nat Neurosci 2005, 8:1440-1441.

17. Crews FT, Nixon K: Mechanisms of neurodegeneration and regeneration in alcoholism. Alcohol 2009, 44:115-127.

18. Khisti RT, Wolstenholme J, Shelton KL, Miles MF: Characterization of the ethanol-deprivation effect in substrains of C57BL/6 mice. Alcohol 2006, 40:119-126.

19. Weitemier AZ, Tsivkovskaia NO, Ryabinin AE: Urocortin 1 distribution in mouse brain is strain-dependent. Neuroscience 2005, 132:729-740.

20. Ryabinin AE: Lesions of the Edinger-Westphal nucleus in C57BL/6J mice disrupt ethanol-induced hypothermia and ethanol consumption. Eur J Neurosci 2004, 20:1613-1623.

21. Ryabinin AE, Yoneyama N, Tanchuck MA, Mark GP, Finn DA: Urocortin 1 microinjection into the mouse lateral septum regulates the acquisition and expression of alcohol consumption. Neuroscience 2008, 151:780-790.

22. Turek VF, Tsivkovskaia NO, Hyytia P, Harding S, Lê AD, Ryabinin AE: Urocortin 1 expression in five pairs of rat lines selectively bred for differences in alcohol drinking. Psychopharmacology 2005, 181:511-517.

23. Ryabinin $A E$, Weitemier $A Z$ : The urocortin 1 neurocircuit: ethanolsensitivity and potential involvement in alcohol consumption. Brain Res Rev 2006, 52:368-380.

24. Samson HH, Tolliver GA, Haraguchi M, Hodge CW: Alcohol self-administration: role of mesolimbic dopamine. Ann N Y Acad Sci 1992, 654:242-253.

25. MCBride WJ, Li TK: Animal models of alcoholism: neurobiology of high alcohol-drinking behavior in rodents. Crit Rev Neurobiol 1998, 12:339-369.

26. Koob GF, Roberts AJ, Schulteis G, Parsons LH, Heyser CJ, Hyytiä P, Merlo-Pich E, Weiss F: Neurocircuitry targets in ethanol reward and dependence. Alcohol Clin Exp Res 1998, 22:3-9.

27. Rodd ZA, Melendez RI, Bell RL, Kuc KA, Zhang Y, Murphy JM, McBride WJ: Intracranial self-administration of ethanol within the ventral tegmental area of male Wistar rats: evidence for involvement of dopamine neurons. J Neurosci 2004, 24:1050-1057.

28. Gessa GL, Muntoni F, Collu M, Vargiu L, Mereu G: Low doses of ethanol activate dopaminergic neurons in the ventral tegmental area. Brain Res 1985, 348:201-203.

29. Brodie MS, Shefner SA, Dunwiddie TV: Ethanol increases the firing rate of dopamine neurons of the rat ventral tegmental area in vitro. Brain Res 1990, 508:65-69.

30. Heilig M, Koob GF: A key role for corticotropin-releasing factor in alcohol dependence. Trends Neurosci 2007, 30(8):399-406.

31. Dyr W, Kostowski W: Evidence that the amygdala is involved in the inhibitory effects of 5-HT3 receptor antagonists on alcohol drinking in rats. Alcohol 1995, 12:387-391.

32. Gilpin NW, Richardson HN, Koob GF: Effects of CRF1-receptor and opioid-receptor antagonists on dependence-induced increases in alcohol drinking by alcohol-preferring (P) rats. Alcohol Clin Exp Res 2008, 32:1535-1542.

33. Hyytiä P, Koob GF: GABAA receptor antagonism in the extended amygdala decreases ethanol self-administration in rats. Eur J Pharmacol 1995, 283:151-159.

34. Roberto M, Madamba SG, Moore SD, Tallent MK, Siggins GR: Ethanol increases GABAergic transmission at both pre- and postsynaptic sites in rat central amygdala neurons. Proc Natl Acad Sci 2003, 100:2053-2058.

35. Roberts AJ, Cole M, Koob GF: Intra-amygdala muscimol decreases operant ethanol self-administration in dependent rats. Alcohol Clin Exp Res 1996, 20:1289-1298.

36. Möller C, Wiklund L, Sommer W, Thorsell A, Heilig M: Decreased experimental anxiety and voluntary ethanol consumption in rats following central but not basolateral amygdala lesions. Brain Res 1997, 760:94-101.

37. Wee S, Koob GF: The role of the dynorphin-kappa opioid system in the reinforcing effects of drugs of abuse. Psychopharmacology (Berl) 2010, 210:121-135.

38. Walker BM, Valdez GR, McLaughlin JP, Bakalkin G: Targeting dynorphin/ kappa opioid receptor systems to treat alcohol abuse and dependence. Alcohol 2012, 46:359-370. 
39. Sperling RE, Gomes SM, Sypek El, Carey AN, McLaughlin JP: Endogenous kappa-opioid mediation of stress-induced potentiation of ethanol-conditioned place preference and self-administration. Psychopharmacology (Berl) 2010, 210:199-209.

40. McBride WJ: Central nucleus of the amygdala and the effects of alcohol and alcohol-drinking behavior in rodents. Pharmacol Biochem Behav 2002, 71:509-515

41. Dole VP, Gentry RT: Toward an analogue of alcoholism in mice: Scale factors in the model. Proc Natl Acad Sci 1984, 81:3543-3546.

42. Dole VP, Gentry RT: Toward an analogue of alcoholism in mice: Criteria for recognition of pharmacologically motivated drinking. Proc Natl Acad Sci 1985, 82:3469-3471.

43. Nestler EJ: Molecular neurobiology of addiction. Am J Addict 2001, 10:201-217.

44. Nestler EJ, Kelz MB, Chen J: DeltaFosB: a molecular mediator of long-term neural and behavioral plasticity. Brain Res 1999, 835:10-17.

45. Franklin KJ, Paxinos G: The mouse brain in stereotaxic coordinates. 2nd edition. San Diego, CA: Academic; 2001.

doi:10.1186/1471-2202-13-130

Cite this article as: Ozburn et al: Chronic self-administration of alcohol results in elevated $\triangle F$ FosB: comparison of hybrid mice with distinct drinking patterns. BMC Neuroscience 2012 13:130.

\section{Submit your next manuscript to BioMed Central and take full advantage of:}

- Convenient online submission

- Thorough peer review

- No space constraints or color figure charges

- Immediate publication on acceptance

- Inclusion in PubMed, CAS, Scopus and Google Scholar

- Research which is freely available for redistribution 